\title{
Central ring structure identified in one of the world's best-preserved impact craters
}

\author{
A.C. Gebhardt \\ F. Niessen \\ Alfred Wegener Institute for Polar and Marine Research, Columbusstraße, 27568 Bremerhaven, Germany \\ C. Kopsch \\ Alfred Wegener Institute for Polar and Marine Research, Telegrafenberg A43, 14473 Potsdam, Germany
}

\begin{abstract}
Seismic refraction and reflection data were acquired in 2000 and 2003 to study the morphology and sedimentary fill of the remote El'gygytgyn crater (Chukotka, northeastern Siberia; diameter $18 \mathrm{~km}$ ). These data allow a first insight into the deeper structure of this unique impact crater. Wide-angle data from sonobuoys reveal a five-layer model: a water layer, two lacustrine sedimentary units that fill a bowl-shaped apparent crater morphology consisting of an upper layer of fallback breccia with $P$-wave velocities of $\sim 3000$ $\mathrm{m} / \mathrm{s}$, and a lower layer of brecciated bedrock (velocities $>3600 \mathrm{~m} / \mathrm{s}$ ). The lowermost layer shows a distinct anticline structure that, by analogy with other terrestrial and lunar craters of similar size, can be interpreted as a central ring structure. The El'gygytgyn crater exhibits a well-expressed morphology that is typical of craters formed in crystalline target rocks.
\end{abstract}

Keywords: impact crater, El'gygytgyn, lakes, seismic refraction, seismic reflection.

\section{INTRODUCTION}

The El'gygytgyn crater, located in the Russian Arctic, is one of the world's bestpreserved impact craters of its size (Dietz and McHone, 1976), and is the only known crater on Earth that was formed by an impact into siliceous volcanic rocks (e.g., Gurov et al., 1979a, 1979b; Gurov and Koeberl, 2004); its lake is one of only a few inside an impact crater (Lerman et al., 1995). The crater's age, 3.6 Ma (Layer, 2000), and its excellent preservation provide unique information about impact mechanisms and shock metamorphism in siliceous volcanic rock. The lacustrine sediments have never been glaciated (Glushkova and Smirnov, 2005; Minyuk et al., 2003), and so may contain a high-resolution paleoclimate record of the past 3.6 m.y. In a first step toward continental deep drilling, a seismic refraction and reflection survey was carried out to obtain information on the structure of the crater and the geometry of its sedimentary fill (Niessen et al., 2006). Seismic refraction data form the basis of a five-layer velocity-depth model that reveals the structural geometry of the impact crater, and multichannel reflection data provide information on its lacustrine sedimentary fill.

\section{GEOLOGICAL BACKGROUND AND PREVIOUS WORK}

The 18-km-diameter El'gygytgyn crater is located in the remote Anadyr Mountains (Fig. 1) in central Chukotka, northeastern Siberia
(Belyi, 1998; Gurov et al., 1979a, 1979b). The Anadyr Mountains are part of the OkhotskChukotka Volcanic Belt, composed of Late Cretaceous calc-alkaline volcanic rocks (Belyi, 1994; Layer, 2000; Layer et al., 2001). The target rocks are mainly rhyodacite tuffs and ignimbrites, with some rhyolites, andesite tuffs, and basalts. A lake of $\sim 12 \mathrm{~km}$ diameter and $170 \mathrm{~m}$ water depth (Nolan and Brigham-

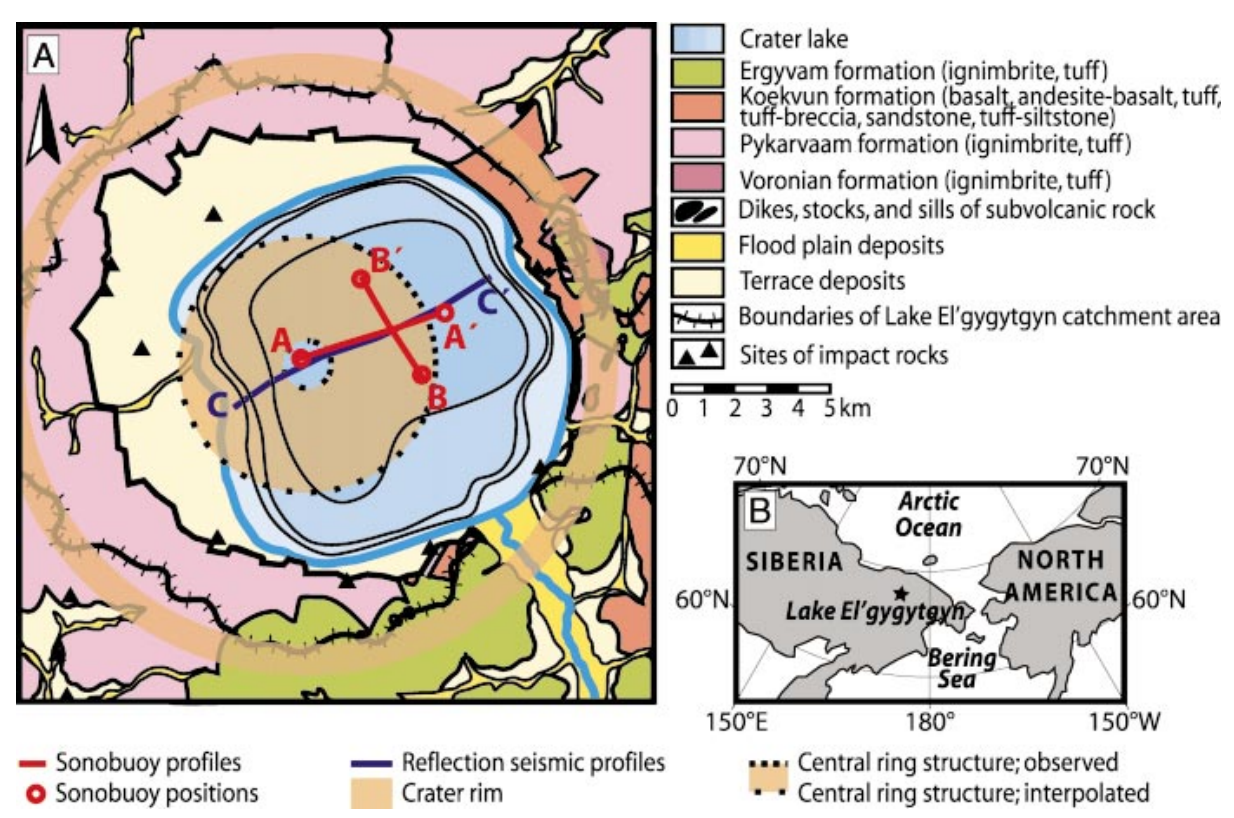

Grette, 2006; Nolan et al., 2002) formed inside the crater (the crater and crater lake are not concentric; see Fig. 1), and has become a major focus of multidisciplinary international research (e.g., Nolan et al., 2002; Nowaczyk et al., 2002) because it could provide a 3.6 m.y. paleoclimatic record unique to the Arctic. When the impact formed the crater, the Arctic was forested, and $\sim 1$ m.y. passed before the

Figure 1. A: Geological overview of crater and its surroundings (modified after Nowaczyk et al., 2002). B: General overview of crater location. Note that crater and crater lake are not concentric.

(C) 2006 Geological Society of America. For permission to copy, contact Copyright Permissions, GSA, or editing @ geosociety.org. Geology; March 2006; v. 34; no. 3; p. 145-148; doi: 10.1130/G22278.1; 4 figures. 

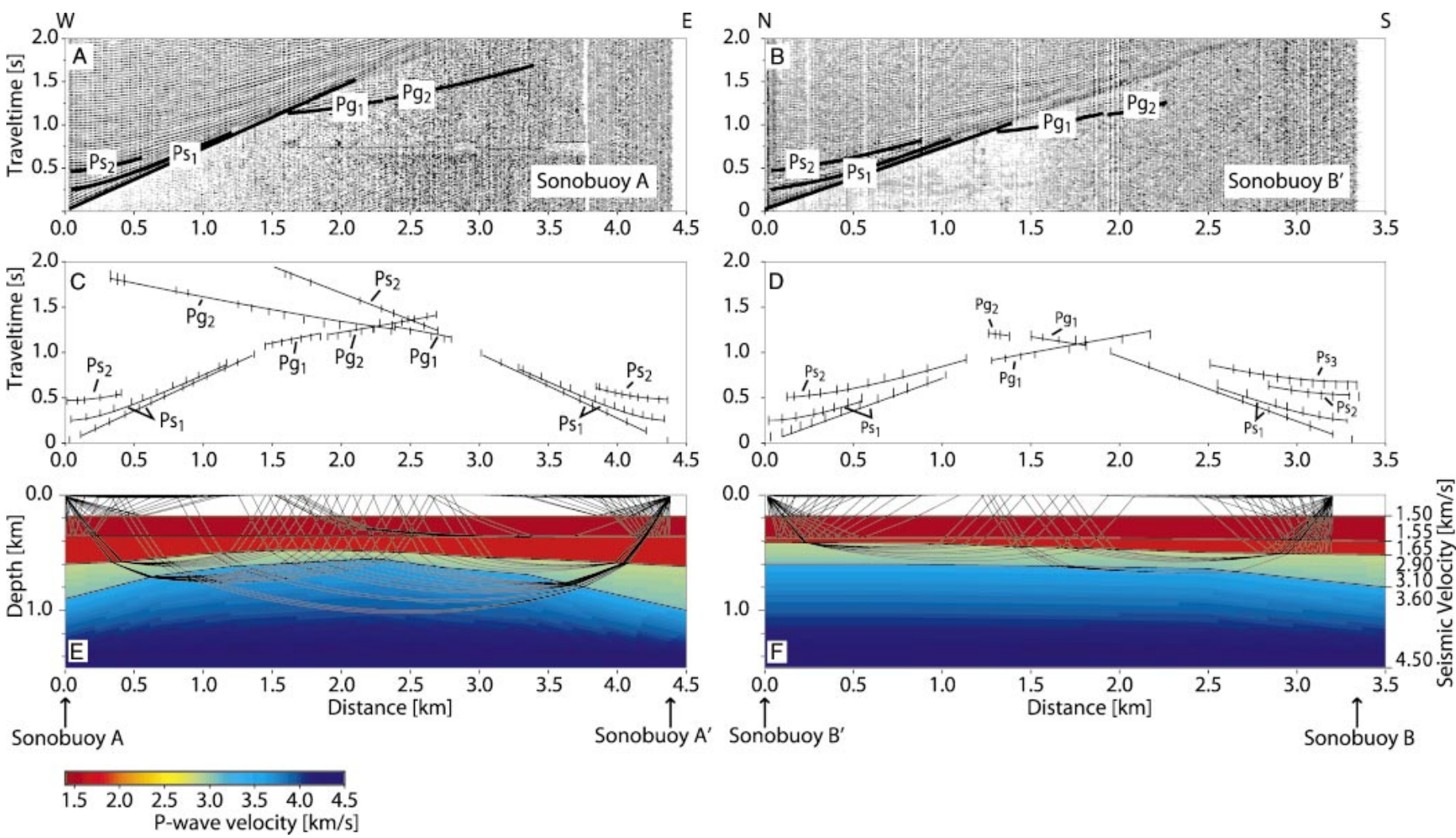

Figure 2. Sonobuoy refraction data. Left: W-E profile. Right: N-S profile. Two seismic record sections are given in upper part (A, B); picked phases are marked as Ps (sedimentary units) and Pg (breccia and bedrock). Observed and calculated traveltimes are shown in C and D. Picks as error bars indicate pick uncertainties, and modeled synthetic rays are lines. Five-layer seismic velocity model is shown in E and F. For locations of profiles and sonobuoys, see Figure 1.

first major glaciation of the Northern Hemisphere (Brigham-Grette and Carter, 1992). Today's lake level is $\sim 500 \mathrm{~m}$ above sea level (asl), and the highest elevations of the crater rim reach $850-950 \mathrm{~m}$ asl; the crater rim forms the outer margin of the catchment area of the lake.

\section{SEISMIC DATA ACQUISITION AND PROCESSING}

During two expeditions in 2000 and 2003, seismic refraction and multichannel reflection data were obtained using 2 sonobuoys and a 260-m-long streamer (Niessen et al., 2005). Due to the remote location (Fig. 1), all geophysical equipment, including the vessel (a 3 $\times 4 \mathrm{~m}$ aluminum platform), had to be transported to the lake by helicopter. For the multichannel survey, a $26 \mathrm{in}^{3}\left(426 \mathrm{~cm}^{3}\right)$ mini-GI gun (triggered in G-gun mode) at a pressure of $110 \mathrm{bar}$ was used. The shot interval was 10 $\mathrm{s}$, resulting in $\sim 12 \mathrm{~m}$ shot distance. A 14 channel streamer with an initial offset of 130 $\mathrm{m}$ and a hydrophone spacing of $10 \mathrm{~m}$ was used as a receiving array. Reflection data were processed in a standard sequence including bandpass filtering (70-90-240-300 Hz), velocity analysis, CMP (common midpoint) stacking, and predictive deconvolution. The final stacking was done using the refraction data velocities for the lower layers (breccia and bedrock).

In 2000, a single $5 \mathrm{in}^{3}\left(82 \mathrm{~cm}^{3}\right)$ Bolt 600B airgun was used as seismic source for the refraction profiles. The shot interval was $6 \mathrm{~s}$, equating to an average of $8 \mathrm{~m}$ shot distance. Two sonobuoys were used on two perpendicular profiles across the center of the crater lake (Fig. 1) and recorded the airgun-borne acoustic pulses by a single hydrophone under the buoy. Signals were amplified and transmitted via radio to the platform (Niessen et al., 2006). Both sonobuoy profiles were reversed. The seismic refraction data recorded by the sonobuoys covered an offset range to $4.4 \mathrm{~km}$ (E-W profile) and $3.3 \mathrm{~km}$ (N-S profile, Fig. 2) and were improved by standard processing (bandpass filtering 3-5-50-60 $\mathrm{Hz}$, AGC) to identify different reflection and refraction phases. Picking and modeling of the identified phases (Pg and Ps, Fig. 2) were done using the "zplot" and "rayinvr" program package (Zelt and Smith, 1992). A forward ray-tracing modeling technique was used to develop a model of layer thicknesses and velocities. The initial five-layer model was used to calculate synthetic seismic traveltimes. It was iteratively modified until the calculated and observed traveltimes were concordant (Fig. 2B). Modeling uncertainties for the central ring struc- ture are $\sim 50 \mathrm{~m}$ in the central part and $\sim 80 \mathrm{~m}$ in the more distal part of the refraction data.

\section{RESULTS AND INTERPRETATION}

The final five-layer model (Fig. 2) includes a water layer and two upper sedimentary units of low seismic velocities $(1550 \mathrm{~m} / \mathrm{s}$ and 1650 $\mathrm{m} / \mathrm{s}$ ); the upper unit (Ia) is $170 \mathrm{~m}$ thick, and the lower unit (Ib) is 190-250 m thick. These units are underlain by a unit with a distinctly higher seismic velocity of $\sim 3000 \mathrm{~m} / \mathrm{s}$ and a thickness of 100-400 m (unit II). The lowermost unit (III) has a seismic velocity of $>3600 \mathrm{~m} / \mathrm{s}$

The most striking feature revealed by the sonobuoy data is the clearly visible uplift structure in the lowermost layer of our model. Its position in the two perpendicular profiles shows that it is located in the southwestern part of the lake (Fig. 1), $\sim 2 \mathrm{~km}$ away from the crater center. Complex impact craters are characterized by a central uplift area consisting of a central topographic peak and/or ring(s) (Grieve and Pesonen, 1992). The crater morphology is strongly related to its size and target rock (Grieve and Pesonen, 1992; Spudis, 1993). Grieve and Pesonen (1992) reported a central uplift morphology succession from craters with a simple central peak (e.g., Steinheim crater, Flynn Creek crater, both with 


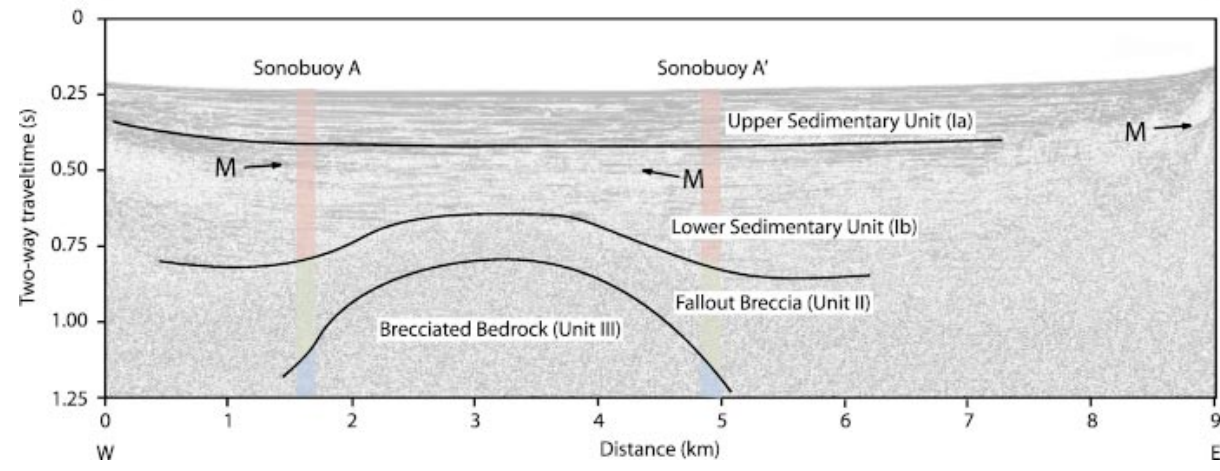

Figure 3. Reflection profile along W-E sonobuoy profile. Locations of profile and sonobuoys are given in Figure 1. Colors at sonobuoy positions correspond to Figure 2. M-multiples. diameters of $3.8 \mathrm{~km}$ ), to craters whose central peak basins consist of both a central peak and a surrounding ring (e.g., Mistastin crater, 28 $\mathrm{km})$, to large craters with one or several rings, but without a central peak (e.g., West Clearwater crater, 32 km; Puchezh Katurki crater, $80 \mathrm{~km}$; Popigai crater, $100 \mathrm{~km}$; Sudbury crater, $250 \mathrm{~km}$ ). The transition between the different types depends on the target rock (Spudis, 1993, and references therein). According to our work, the El'gygytgyn crater (18 km) is likely to have a central uplift structure several kilometers in diameter, rather than a single central peak. The uplift structure observed in the sonobuoy data is clearly not in the center of the crater, and we think that it corresponds to the northeastern flank of a central ring; there is no evidence for a central peak within this ring. Figure 1 shows the position of the proposed central ring. The layer forming the ring is characterized by seismic velocities of $>3600 \mathrm{~m} / \mathrm{s}$ and is interpreted to consist of parautochthonous bedrock forming the crater floor. P-wave velocities in hand specimens of bedrock outcrops around the lake are generally much higher $(\sim 4950 \mathrm{~m} / \mathrm{s}$, Niessen et al., 2006). This suggests that the bedrock is brecciated at least in its upper part, as is the case in other craters (e.g., Bosumtwi crater, Ghana, Africa; Karp et al., 2002; Scholz et al., 2002). The central ring structure is overlain by a layer interpreted as allochthonous fallback breccia characterized by seismic velocities of $\sim 3000 \mathrm{~m} / \mathrm{s}$. This breccia is almost level over

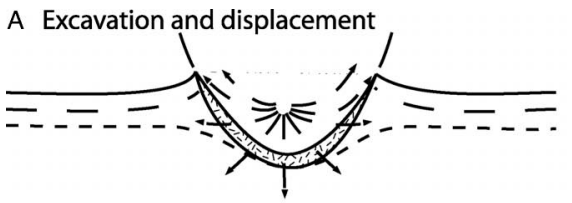

B Formation and collapse of uplift and rim
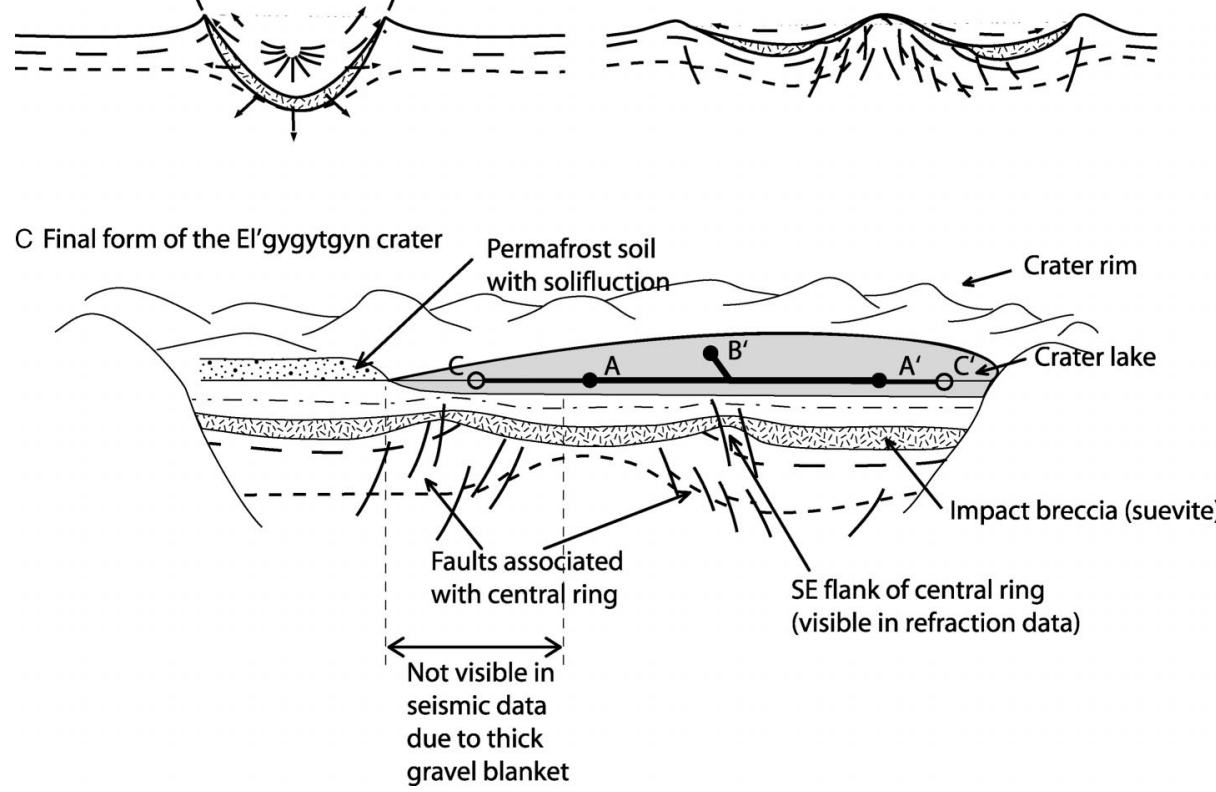

Figure 4. Model of El'gygytgyn crater formation (modified after Heiken et al., 1991) during impact (A), immediately after impact (B), and at present (C). Erosion seems to be much higher in northwestern part of crater, causing large areas to be filled with coarse sediments, and consequently lake is not located in center of crater. Permafrost soil and solifluction were observed in northwestern part of lake. Coarse sediments (e.g., gravel) are also observed in northwestern part of lake, limiting acoustic penetration in this area. the central uplift structure and is $100 \mathrm{~m}$ thick on top of the central ring, increasing to $400 \mathrm{~m}$ thick in the surrounding annular basin. Comparable layers have been found, for example, in the Bosumtwi crater (velocities of $\sim 3200$ m/s; Karp et al., 2002; Scholz et al., 2002) and in the Nördlinger Ries crater (e.g., Engelhardt et al., 1994; Wünnemann and Morgan, 2004).

Seismic velocities are much lower within the lacustrine layers, averaging $1550 \mathrm{~m} / \mathrm{s}$ in the upper and $1650 \mathrm{~m} / \mathrm{s}$ in the lower sedimentary unit. The lower sedimentary unit shows a slight drape on top of the central uplift, whereas the contact between the two sedimentary units is almost flat. Reflection seismic data (Fig. 3) show a well-stratified 170-mthick upper unit that is locally intercalated with debris flows, mainly at the lake margins. The lower unit is more massive and is 190$250 \mathrm{~m}$ thick. Considering an age of $3.6 \mathrm{Ma}$ and a lacustrine fill thickness of 360-420 m, an average sedimentation rate of $0.1-0.12$ $\mathrm{mm} / \mathrm{yr}$ can be estimated.

\section{DISCUSSION}

The El'gygytgyn impact event created an impact structure with a diameter of $18 \mathrm{~km}$ and a central uplift morphology that consists of a concentric inner ring (Fig. 4). Because a thick blanket of gravel limits acoustic penetration in the western part of the lake, the western part of the central ring cannot be observed in the seismic data (Figs. 2 and 4C). The existence of a central ring is in good agreement with gravity data that showed a generally negative anomaly with a local positive anomaly $\sim 3 \mathrm{~km}$ northwest of the lake center (Alyunin and Dabizha, 1980).

The Ries crater in southern Germany has a diameter of $25 \mathrm{~km}$ and shows an outer ring forming the crater rim, an inner concentric ring, and a central peak. Wünnemann and Morgan (2004) showed that the results of numerical models of impact craters are dependent on the target rock. Impacts into crystalline rock result in more pronounced structural elements, whereas impacts into sedimentary rock exhibit a relatively flat morphology. The Ries crater target rock consists mainly of crystalline bedrock, and its sedimentary cover supported the formation of a large megablock zone (Wünnemann and Morgan, 2004); this zone is less pronounced in the El'gygytgyn crater (Gurov and Koeberl, 2004). Even though the El'gygytgyn crater is smaller than the Ries crater, its morphology is more complex, according to Grieve and Pesonen (1992). This probably means that the crater morphology is even more pronounced in siliceous volcanic target rock than in crystalline target rock due to different petrological and rheological behavior of the target rock. 
On an analysis of five complex terrestrial craters, Grieve and Pesonen (1992) concluded that, within complex crater structures formed in crystalline bedrock, the width and height of the crater structures roughly follow the relationship

$$
d_{\mathrm{a}}=0.15 D^{0.43},
$$

where $d_{\mathrm{a}}$ is the apparent crater depth (i.e., from the crater rim to the top of the breccia) and $D$ is the diameter of the crater. Considering an apparent crater depth of $\sim 1 \mathrm{~km}$, and a crater diameter of $18 \mathrm{~km}$, the El'gygytgyn impact formed a topographic relief that is about twice as pronounced as expected from equation 1. This could be due to differences between crystalline bedrock and siliceous volcanic bedrock, or the fact that five craters are insufficient to calculate reliable relationship equations.

The uplift structure observed in the sonobuoy profiles is $\sim 3 \mathrm{~km}$ wide (Fig. 3). Its asymmetric position within the crater is abnormal in comparison with other crater studies, and suggests that only parts of a wider and more complex central uplift structure are visible in the seismic records. Interpolating a concentric ring structure from the visible northeastern flank of the uplift results in a ring structure with a diameter of $\sim 7-7.5 \mathrm{~km}$ (Fig. 1). Data from lunar craters show that complex craters with diameters of $18 \mathrm{~km}$, like the El'gygytgyn, commonly have central peak diameters of $\sim 2.5-4 \mathrm{~km}$ (Spudis, 1993, and references therein). However, lunar and terrestrial craters cannot be directly compared due to the different lunar and terrestrial gravity fields.

\section{SUMMARY}

The El'gygytgyn crater, the only known terrestrial crater with a siliceous target rock, shows a distinct morphology with a central ring structure of $\sim 7-7.5 \mathrm{~km}$ in diameter and a minimum height of $\sim 350 \mathrm{~m}$. This ring structure is formed in the bedrock, which is brecciated to depths of at least a few hundreds of meters. The ring structure topography is almost buried by an overlaying fallback breccia unit. The crater lake sediments consist of an upper and a lower sedimentary unit characterized by the low velocities of unconsolidated mud.

\section{ACKNOWLEDGMENTS}

We thank the 2000 and 2003 expedition members for their excellent cooperation and support during work at the lake. Financial support by the German Ministry of Education and Research (BMBF grant 03G0586B) is gratefully acknowledged.

\section{REFERENCES CITED}

Alyunin, A.V., and Dabizha, A.I., 1980, Geophysical characteristics of meteoritic crater El'gygytgyn, USSR, in Proceedings, Lunar and Planetary Science Conference XI: Houston, Texas, Lunar and Planetary Institute, p. 21-23.

Belyi, V.F., 1994, Geology of Okhotsk-Chukchi volcanogenic belt: Magadan, Northeastern Integrated Scientific Institute, $76 \mathrm{p}$.

Belyi, V.F., 1998, Impactogenesis and volcanism of the El'gygytgyn depression: Journal of Petrology, v. 6, p. 96-110.

Brigham-Grette, J., and Carter, L.D., 1992, Pliocene marine transgression of northern Alaska: Circumarctic correlations and paleoclimate: Arctic, v. 43, p. 74-89.

Dietz, R.S., and McHone, J.F., 1976, El'gygytgyn: Probably world's largest meteorite crater: Geology, v. 4, p. 391-392.

Engelhardt, W.V., Arndt, J., Fecker, B., and Pankau, H.G., 1994, Ries impact crater, Germany: Thermal history of the suevite breccia: Meteoritics, v. 29, p. 463-464.

Glushkova, O. Y., and Smirnov, V., 2005, General geology and geography: Reports on Polar and Marine Research, v. 509, p. 14-18.

Grieve, R.A.F., and Pesonen, L.J., 1992, The terrestrial impact cratering record: Tectonophysics, v. 216 , p. $1-30$

Gurov, E.P., and Koeberl, C., 2004, Shocked rocks and impact glasses from the El'gygytgyn impact structure (Russia): Meteoritics and Planetary Science, v. 39, p. 1495-1508.

Gurov, E.P., Gurova, E.P., and Rakitskaya, R.B., 1979a, Stishovite and coesite in shock metamorphosed rocks of the El'gygytgyn crater in Chukotka (in Russian): Akademiya Nauk SSSR Doklady, v. 248, p. 213-216.

Gurov, E.P., Valter, A.A., Gurova, E.P., and Kotlovskaya, F.I., 1979b, El'gygytgyn impact crater, Chukotka: Shock metamorphism of volcanic rocks [abs.], in Proceedings, Lunar and Planetary Science Conference X: Houston, Texas, Lunar and Planetary Science Institute, p. 479-481.

Heiken, G., Vaniman, D., and French, B., 1991, The lunar sourcebook: Cambridge, Cambridge University Press, $736 \mathrm{p}$

Karp, T., Milkereit, B., Janle, P., Danuor, S.K., Pohl, J., Berckhemer, H., and Scholz, C.A., 2002, Seismic investigation of the Lake Bosumtwi impact crater: preliminary results: Planetary and Space Science, v. 50, p. 735-743.

Layer, P., 2000, ${ }^{40} \mathrm{Ar} /{ }^{39} \mathrm{Ar}$ age of the El'gygytgyn crater event, Chukotka, Russia: Meteoritics \& Planetary Science, v. 35, p. 591-599.

Layer, P., Newberry, R., Fujita, K., Parfenov, L., Trunilina, V., and Bakharev, A., 2001, Tectonic setting of the plutonic belts of Yakutia, northeast Russia, based on ${ }^{40} \mathrm{Ar} /{ }^{39} \mathrm{Ar}$ geochronology and trace element geochemistry: Geology, v. 29, p. 167-170.

Lerman, A., Imboden, D., and Gat, J., 1995, Physics and chemistry of lakes: Berlin, Heidelberg, Springer, $334 \mathrm{p}$.

Minyuk, P., Nowaczyk, N., Glushkova, O.Y., Smirnov, V., Brigham-Grette, J., Melles, M., Cherepanova, M., Lozhkin, A., Anderson, P., Matrosova, T., Hubberten, H., Belaya, B.V., Borkhodoyev, B.Y., Forman, S., Asikainen, C.A., Layer, P., Nolan, M., Prokein, P., Liston, G., Huntzinger, R., Sharpton, V., and Niessen, F., 2003, Paleoclimatic characteristics of Lake El'gygytgyn, NE Russia-Multidisciplinary investigation (in Russian), in Malakhov, M.I., ed., The process of post-depositional magnetization and characteristic changes of the Earth's magnetic field and climate in the past: Magadan, Northeastern Integrated Scientific Institute FEB RAS, p. 91-135.

Niessen, F., Gebhardt, A.C., and Kopsch, C., 2005, Geophysical survey: Reports on Polar and Marine Research, v. 509, p. 121-129.

Niessen, F., Gebhardt, A.C., Kopsch, C., and Wagner, B., 2006, Seismic investigation of the El'gygytgyn impact crater lake (Central Chukotka, NE Siberia): Preliminary results: Journal of Paleolimnology, Special Issue (in press).

Nolan, M., and Brigham-Grette, J., 2006, Basic hydrology, limnology, and meteorology of modern Lake El'gygytgyn, Siberia: Journal of Paleolimnology, Special Issue (in press).

Nolan, M., Liston, G., Prokein, P., Brigham-Grette, J., Sharpton, B., and Huntzinger, R., 2002, Analysis of lake ice dynamics and morphology on Lake El'gygytgyn, NE Siberia, using SAR and Landsat: Journal of Geophysical Research, v. 107, p. doi: 10. 1029/2001JD 000934.

Nowaczyk, N.R., Minyuk, P., Melles, M., BrighamGrette, J., Glushkova, O., Nolan, M., Lozhkin, A.V., Stetsenko, T.V., Andersen, P.M., and Forman, S.L., 2002, Magnetostratigraphic results from impact crater Lake El'gygytgyn, northeastern Siberia: A 300 kyr long highresolution terrestrial palaeoclimatic record from the Arctic: Geophysical Journal International, v. 150 , p. 109-126.

Scholz, C.A., Karp, T., Brooks, K.M., Milkereit, B., Amoako, P.Y.O., and Arko, J.A., 2002, Pronounced central uplift identified in the Bosumtwi impact structure, Ghana, using multichannel seismic reflection data: Geology, v. 30 , p. $939-942$.

Spudis, P.D., 1993, The geology of multi-ring impact basins: The moon and other planets: New York, Cambridge University Press, 263 p.

Wünnemann, K., and Morgan, J.V., 2004, Investigation of the Ries impact crater based upon old and new geophysical data and numerical modeling, in Proceedings, Lunar and Planetary Science Conference XXXV: Houston, Texas, Lunar and Planetary Institute, p. 1229.

Zelt, C.A., and Smith, R.B., 1992, Seismic traveltime inversion for 2-D crustal velocity structure: Geophysical Journal International, v. 108 , p. $16-34$

Manuscript received 26 September 2005

Revised manuscript received 1 November 2005

Manuscript accepted 7 November 2005

Printed in USA 